\title{
ROM OG RETT
}

Av Beate Ellingsen

Vår ydmykhet for å gå igang med innredningen av Oslo Tinghus var stor.

Prosjektet ble påbegynt i 1990. Statsbygg står for både bygg og interiør. Innredning er noe de meget sjeldent har ansvaret for og spesielt med et så viktig bygg. Vi fikk oppdraget to år før ferdigstillelse og måtte kaste oss rundt på slutten av året for å utarbeide kostnadsoverslag og få dette med på riktig budsjettår.

Parallelt med iherdig innsats for å forstå problematikken omkring husets innhold med de mange embeder, ekspedisjoner, rettssaler, fellesareal m. m., gjaldt det å forstå det arkitektoniske uttrykket, som Østgård arkitekter arbeidet med.

Vår første utfordring som interiørarkitekter er i dypeste forstand å forstå intensjonene med et hus. Denne forståelsen er helt avgjørende for gleden av å arbeide med innredningen mot et samlet mål. I nært samarbeid med brukere blir imidlertid vårt dilemma ofte loyaliteten mot de overordnede arkitektoniske intensjonene og de rene funksjonelle ønsker fra brukerne.

På det tidspunkt vi ble innlemmet i prosjekteringen av Oslo Tinghus var romdisposisjonen gitt. Arkitektene har ansvaret for all bygningsmessig detaljering, belysning og tekniske installasjoner. Dette er, for alle, et kunstig og uheldig skille $\mathrm{i}$ arbeide med utforming av helhetlige rom. Ansvarsdelingen setter store krav til et nært samarbeide.

Vår oppgave var å innrede huset som inneholder ca. 450 arbeidsplasser med tilhørende ekspedisjonslokaler, 2 vigselsrom, fellesarealer og 52 rettssaler med tilhørende støtterom. Oppgaven var på mange måter todelt, med kontorinnredning som en mer kjent problemstilling, og innredningene av rettssalene som derimot var en enorm faglig utfordring.

Oslo Tinghus rommer Oslodomstolene representert ved Oslo Byrett som har 36 saler, Oslo Byfogedembede og Oslo Skifterett som begge har 3 saler.

Eidsivating Lagmannsrett representerer 2. instans og har 10 saler.

Planløsning av salene kan i utgangspunktet være ganske lik. Bortsett fra antall dommere som kan variere fra 1 til 7, representerer juryordningen for Lagmannsretten den største forskjellen, da disse fordrer 10 plasser sentralt i rommet.

\section{ET LUKKET ROM}

En rettssal forbindes umiddelbart med et lukket, hemmelig rom. Et rom vi ikke får vite mye om. Et rom som er mørkt og avsondret fra resten av verden. Men så er det i virkeligheten omvendt. Rettssalen er et offentlig rom, et tilgjengelig rom, som tvert imot skal være åpent for publikum og presse. Dette fordi det 


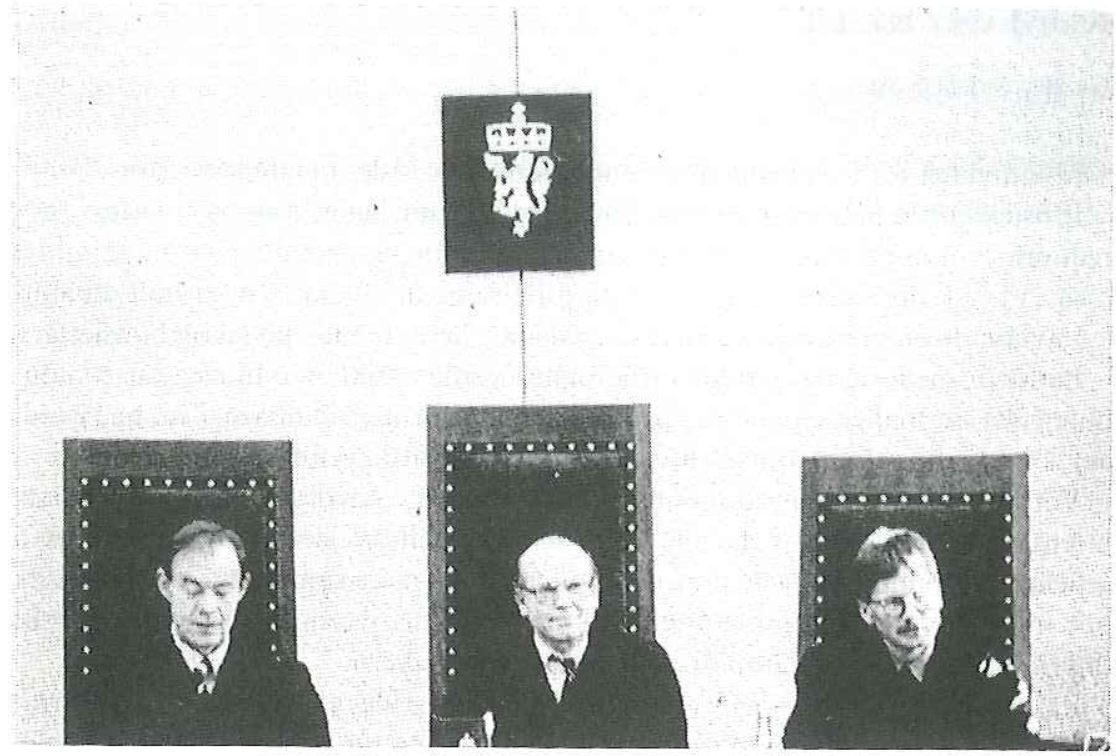

skal være en mulighet for alle til å følge med på det som blir sagt og gjort. Prosessen og domsavsigelsene skal komme offentligheten for øre, - som kontrollerende organ.

Videre er det en arbeidsplass for mange mennesker. Rettssakene kan være lange og til tider monotone. Fysisk sett blir det et veldig statisk arbeid, - komfort og lys betyr mye.

Innredning av rettssalene ukrystalliserte seg i 4 problemområder:

planlosning, dimensjonering, materialvalg, bruk av symbolverdier . . . Alle virker svært avgjørende inn på hvordan rommet oppleves. Små variasjoner i dimensjonering som høyde og tykkelse på oppkanten på dommerbord innvirker merkbart på de menneskelige relasjoner og psykiske barrierer. Dette er ikke fremmed, men virkemidlene blir så sterke når det er en rettssal vi arbeider med.

Det dreier seg om nærhet, avstand, trygghet, alvor, gjenkjennelse, respekt, konsentrasjon, komfort og ydmykhet.

Det gjelder for alle.

For den tiltalte som skal være trygg nok til å forstå hva som blir sagt,

For vitne som skal formidle sannheten,

For advokatene som skal få sin sak hørt,

For dommerne som skal holde orden og finne løsninger,

For presse og publikum som skal klare å følge med på alt som blir sagt. 


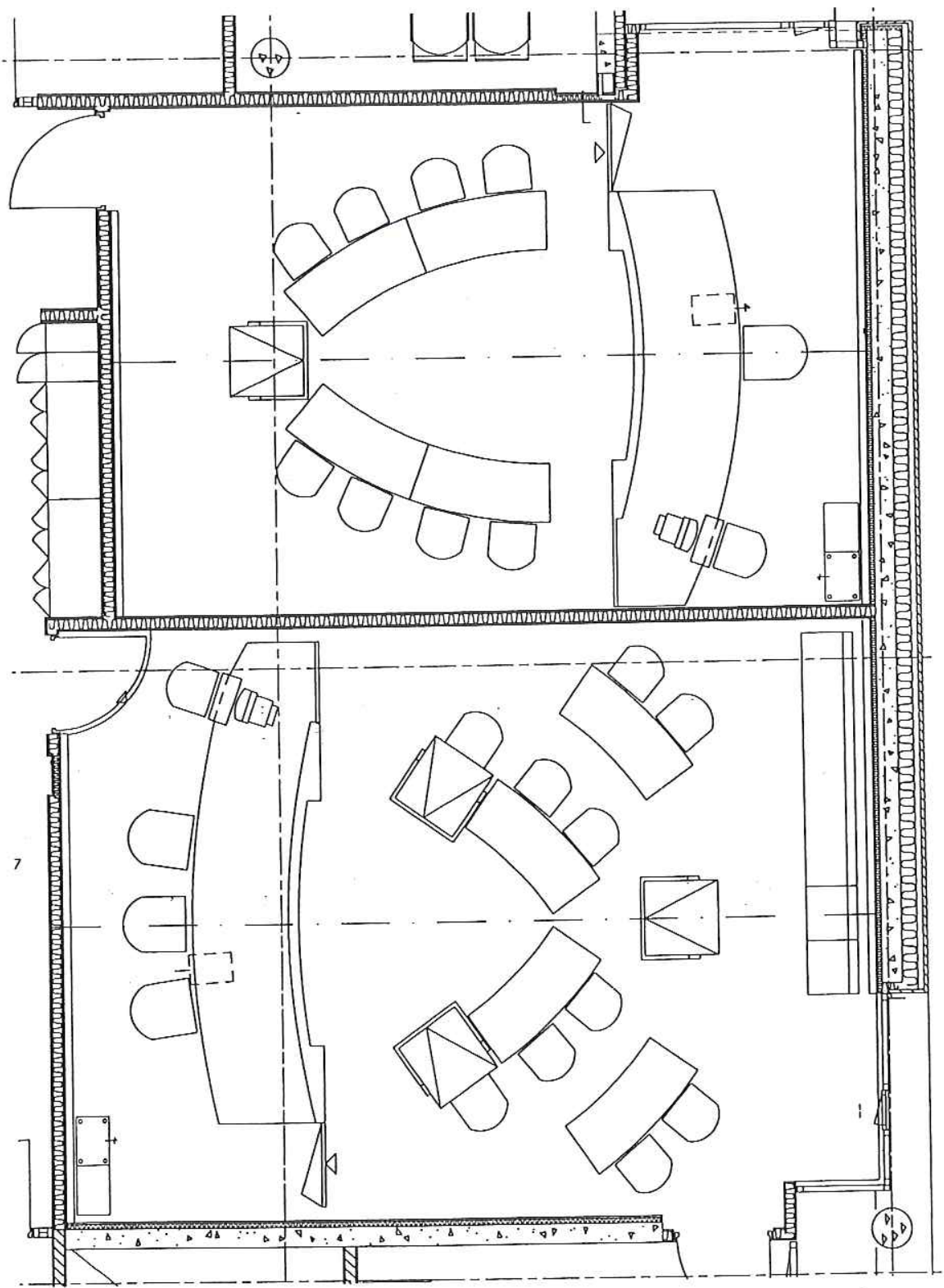


Det viktige for alle er den innbyrdes kommunikasjon. Denne går alle veier, mellom aktor og forsvarer fra partsbordene, mellom aktor/forsvarer og vitneboks, mellom vitneboks og dommerbord og mellom dommerbord og partsbord.

Midtaksen i rommet blir utgangspunktet for å rydde opp og gi balanse, strukturere mennesker og hva de representerer. Aldri var det mere naturlig å ta midtaksen som utgangspunkt for alle valg! Aldri har vi møtt større forståelse for akser og symmetri enn hos dommerne!

Det er viktig å skille mellom sivile saker og straffesaker.

Sivile saker er i sin natur annerledes, med to likeverdige parter.

I straffesaker er påtalemyndighetene representert ved aktor. Tiltalte kommer fra arrestantheisen ledet av politiet, som også er til stede under rettssaken.

Antall deltakere for hver av partene er således mere likeverdige i sivile saker enn i straffesaker. For fleksibel bruk av salene er det imidlertid fornuftig å utnytte rommet med flest mulig partsplasser på hver side.

Den tradisjonelle norske planløsningen er med rette dommerfronter, aktørbordene vinkelrett på disse, vitneboksen i aksen bakover i rommet, publikum og presse bakerst. Partene, det vil si aktor og forsvarer, står vanligvis ved sine egne plasser og prosederer. Nye tider med større bruk av AV-tekniske hjelpemidler vil ventelig innvirke på dette. Da det tekniske utstyret fordrer en sentral plassering med en tilknyttet talerstol.

I den tradisjonelle oppstilling med aktørbordene vinkelrett på dommerbordet snakker partene til hverandre, uten retning mot dommerbordet. Dette var i utgangspunktet ønskelig fra mange vi hadde med å gjøre fra brukerne i Oslo Tinghus. Dette synes imidlertid uheldig ut i fra hensynet til innbyrdes kommunikasjon.

Avstand og arealdisposisjon blir viktige faktorer, idet stor fysisk avstand skaper større psykisk avstand. Dette kan skje med avstand på samme gulvnivå eller ved nivåforskjeller og har stor innvirkning på opplevelsen av trygghet og nærhet, - eller det motsatte.

\section{ANDRE EKSEMPLER}

Det finnes eksempler på alternative saler bl. a. i Trondheim, der planløsningen er sirkulær. Alle snakker fra samme talerstol. Denne står bak vitneboksen.

I høyesterett møter kun aktor og forsvarer. Her er planløsningen basert på prinsippet om at partene står i en rett skranke vis a vis dommerbordet. Dommerbordet er i hestesko, dette understreker formannplassen og gir maksimal kommunikasjon dommerne imellom. Til tross for dette, opplevet vi en inngrodd skepsis til eksperimentering.

Eksempel fra England og Old Bailey viser dommere som fremdeles går med parykk og kappe. De går rundt i søylehallene og ser ut som de tilhører en annen 